\title{
Shackled Orange: Biofortified Varieties in the Sweetpotato Commodity Chain in Mozambique
}

\author{
Roland Brouwer $^{1} \&$ Ilaria Tedesco ${ }^{2}$ \\ ${ }^{1}$ International Potato Center, CIP, Hawassa, Ethiopia \\ ${ }^{2}$ Natural Resources Institute (NRI), University of Greenwich, Kent, United Kingdom and International Fund for \\ Agricultural Development (IFAD), Rome, Italy \\ Correspondence: Roland Brouwer, International Potato Center, CIP, Hawassa, Ethiopia
}

Received: February 12, 2019 Accepted: March 8, 2019 Online Published: April 5, 2019

doi:10.5539/sar.v8n2p55 URL: https://doi.org/10.5539/sar.v8n2p55

\begin{abstract}
Biofortified, orange-fleshed sweetpotato (OFSP) varieties are being promoted as a part of a strategy to reduce Vitamin A Deficiency among rural and urban populations in Sub-Saharan Africa. This paper uses the commodity chain approach to understand whether markets may stimulate or not the production of the new orange sweetpotato varieties on Mozambique's main consumer market, Maputo, its capital and largest city. It shows that the chain linking rural producers to the city's consumers is operated by private actors; the government provides basic infrastructures and price information. International donors are involved through the dissemination of planting material and nutrition information in support the marketing of OFSP. The commodity chains of white and orange-fleshed varieties are entwined with no clear price differences. The annual marketed volume is estimated at 8,000 tonnes, mostly produced by smallholders and sold to consumers by sidewalk and open-air market retailers. This market segment is dominated by women. A small group of specialized - male and female commercial OFSP producers supplies about $0.5 \%$ to $1 \%$ of this market selling directly to a specific group of clients who either buy at farm gate or through home delivery. The conclusion is that the existing commodity chain fails to stimulate the production of OFSP and the expansion of its benefits to wider sections of the population suggesting that the emphasis should be on having biofortified varieties that can compete successfully with the conventional ones at the farm-level.
\end{abstract}

Keywords: biofortification, commodity chain, Mozambique, sweetpotato

\section{Introduction}

Vitamin A Deficiency (VAD) is a poverty-related micronutrient deficiency that still affects a significant percentage of the population in Africa. VAD remains the leading cause of preventable severe visual impairment and blindness and is a significant contributor to severe infections and death as it increases vulnerability to other illnesses. The impact of VAD is most critical among pregnant and lactating women, and infants and pre-schoolers (Underwood \& Arthur, 1996) (West \& Darnton-Hill, 2008). In Mozambique, VAD among mothers of children under five years of age is $11 \%$; with $69 \%$ of the children under five suffering from VAD (15\% grave and 54\% moderate) (Ministério da Saúde de Moçambique [MISAU], 2010). To reduce VAD there are two main strategies: vitamin A supplementation through capsules or pills, or food-based approaches through dietary changes (Ruel, 2001) (Low et al., 2007) .

Food-based approaches are used in many low-income countries to tackle malnutrition traps (Demment, Youngy, \& Sensenig, 2003). Biofortification helps improve the nutritional quality of food crops through agronomic practices, conventional plant breeding, or modern biotechnology (WHO, 2016). To tackle VAD, biofortification has been promoted by increasing the beta-carotene contents of staple crops such as cassava, maize, rice and sweetpotato. Orange-fleshed sweetpotato (OFSP) varieties are one of its most successful cases with conclusive evidence of nutritional effect (Ruel, Alderman, \& The Maternal and Child Nutrition Study Group, 2013). The success of OFSP has been internationally acknowledged with Time Magazine selecting OFSP among the 25 best inventions of 2016 (Time Magazine, 2018). In Mozambique, OFSP varieties have been promoted for over fifteen years, but only since 2011 locally bred varieties have been released that are adapted to local agro-ecologies and sensory preferences. 
To be successful, a food-based approach cannot be only limited to introducing a biofortified food. It requires additional inputs, including nutrition education, gender considerations, and agricultural planning (Blasbalg, Wispelwey, \& Deckelbaum, 2011). Brito, Brouwer and Falcão (2012) emphasize that improved sweetpotato varieties easily reach poorer strata of a community, as it is a vegetatively multiplied crop generally shared among community members.

With support of international donors, the International Potato Centre (CIP) has developed a three-pronged strategy: (a) breeding, multiplication and dissemination of beta-carotene rich OFSP varieties adapted to local agro-ecologies and smallholder farming systems, (b) dissemination of information about the importance of a balanced diet including beta-carotene rich food items such as papaya, mango and OFSP, and (c) increasing access to roots through the marketing of fresh and processed sweetpotato products. In Mozambique, three processed products are currently being developed and promoted: OFSP bread, OFSP juice and OFSP-soy biscuits. The latter aims to combine OFSP with the emerging soy bean value chain (Smart \& Hanlon, 2014) and at this stage is still unique to Mozambique.

The success of the three-pronged strategy depends on three factors: the availability of planting material with the right genetic characteristics (e.g. yield, dry matter, taste, drought tolerance and beta-carotene content) and appropriate quality (e.g. no weevil damage) at a sufficiently large scale; a network of promoters who can disseminate agronomic and nutrition information into producers' communities; and a fully functioning commodity chain that brings the roots from farmers to consumers. However, the results of a CIP survey run in June 2014 raised questions about the effectiveness of the sweetpotato commodity chain as they showed that $90 \%$ of the residents of Maputo City who do not consume OFSP allege that they are not available on the market.

The goal of our paper is to understand the sweetpotato commodity chain and identify the factors that influence the presence of OFSP roots in urban markets. This investigation is done by identifying actors and activities, estimating volumes and mapping the distribution of costs and benefits.

Several authors have studied sweetpotato commodity chains in other developing countries. Degu, Uragie, Zeberga, Musemil, and Adane (2015) look at the sweetpotato market in Ethiopia finding backward and forward linkages with seed system and margins increasing along the chain. Mmasa and Msuya (2012) and Mmasa, Msya and Mlambiti (2013) analysis of the sweetpotato chain in Tanzania shows that here it is well integrated with farmers selling fresh roots as well as processed food, noting the lack of transparency regarding information about supply, demand and prices. In Western Kenya Tedesco and Stathers (2015) investigate the sweetpotato value chain finding limited cultivation of OFSP in their focal counties despites high profits reported by farmers. Chang and Kewa (2014) provide a description of the sweetpotato chain in Papua New Guinea and identify different obstacles to its operation such as access to credit, transport infrastructure, and support services, as well as issues related to postharvest handling, market institutions, and chain coordination.

This paper builds on the results of a study of the sweetpotato commodity chain carried out during 2014-2015 in two provinces in Mozambique: Manica in the centre, and Maputo in the south. To the best of our knowledge, this is the first attempt to study in detail the sweetpotato commodity chain in Mozambique.

\section{Material and Methods}

Originated by Coase (1937) and deepened by Williamson (1971), the commodity (value) chain concept is based on the idea of vertically integrated activities and agents to rule a cost-effective transaction between different stages of a production process. Upstream and downstream activities are interconnected by physical and monetary flows from one activity to another. Segments of the chain may be supply- or demand-driven. The flow of money upward through the chain is the main feedback loop mechanism (Minegishi \& Thiel, 2000), but may be corrected or complemented by government interventions, for example to achieve environmental or equity goals (Sundkvist, Milestad, \& Jansson, 2005). Economic geographers such as Rodrigue, Comtois and Slack (2013) focus on the commodity chain as a process through which goods are moved from production sites to consumption markets. Development economists try to use it as a tool to understand the global distribution of wealth. Raikes, Jensen and Po (2011) distinguish two traditions: the Anglophone Global Commodity Chain which originally focused on industrial commodities and the Francophone filiére approach which goes back to research of agricultural commodities. The latter has been dominated by an empirical research tradition with the main objective of mapping out actual commodity flows and identifying agents and activities and issues of governance and power (Raikes, Jensen, \& Ponte, 2011).

This paper borrows from all these approaches. However, it does not address a globalized commercial system but limits itself to one region in one country and concentrates on one single agricultural commodity. It focuses on agents that connect the producers and consumers in its focal area and tries to establish the costs of production 
and transaction at and between each link, as well as obstacles to the flow of the commodity along the chain. Estimated volumes produced and traded are means to gauge the size of the market.

Similar to Chang and Kewa (2014) and Mmasa and Msuya (2012) different data sources have been used and combined for this study:

(a) Government statistical data and other secondary sources: TIA (Trabalho de Inquérito Agrícola) and IAI (Inquérito Agrário Integrado) surveys for acreages per province and per crop (Ministrério da Agricultura e Segurança Alimentar [MASA], 2015); and market prices from the national market information system SIMA (Sistema de Informação de Mercados Agrícolas de Moçambique). The latter are collected and published weekly (www.sima.masa.org.mz).

(b) Primary data on prices of OFSP sweetpotato roots collected on behalf of CIP by SIMA staff (second semester 2014) and price, origin, variety and estimated turn-over data collected by CIP itself by buying 131 OFSP samples at 16 markets and road-side selling points in Maputo City, between September 2014 and August 2015.

(c) Semi-structured interviews of different agents along the chain, including sweetpotato producers in the Manhiça, Boane and Namaacha districts in Maputo province, retailers at various markets and managers of two important supermarkets.

(d) A survey run by CIP among 656 Maputo City residents aged between 17 and 26 June 2014 about sweetpotato production and consumption.

\section{Results}

\subsection{Geography}

Figure 1 summarizes the geography of sweetpotato supply to Maputo based on field observations and interviews of farmers and traders, and on data collected at markets in Maputo City. The main production area is Manhiça district with $42 \%$ of the 131 orange-fleshed sweetpotato samples collected by CIP during its year-long market monitoring.

The roots are typically produced by smallholders from communities such as Calanga on small plots in the Nkomati River floodplain. Producers take their harvests to a bulking market (Cruz Vermelha) in Manhiça town and sell them to traders. These traders rent space on trucks to transport the produce to Maputo City to the main wholesale market (Zimpeto) and/or mixed wholesale and retail markets such as Xiquelene and Fajardo. Exclusively retailing vendors operating on for example the Central Market and retailers operating small stalls on sidewalks obtain their roots from these wholesale and mixed markets.

The Manhiça farmers produce both white and orange-fleshed varieties. In Boane district there is a small group of specialized farmers around the local agricultural research station who concentrate exclusively on orange-fleshed sweetpotato. These do not supply to traders but sell directly to consumers. These consumers typically come from Maputo City and have their own cars.

Supermarkets play a small role in the commodity chain. The largest supermarkets are either South-African owned (e.g. Shoprite) or franchises of South-African holdings (e.g. Premium Spar). They do not buy sweetpotato from farmers in Mozambique but typically import roots from South Africa, normally Beauregard, a white-fleshed variety.

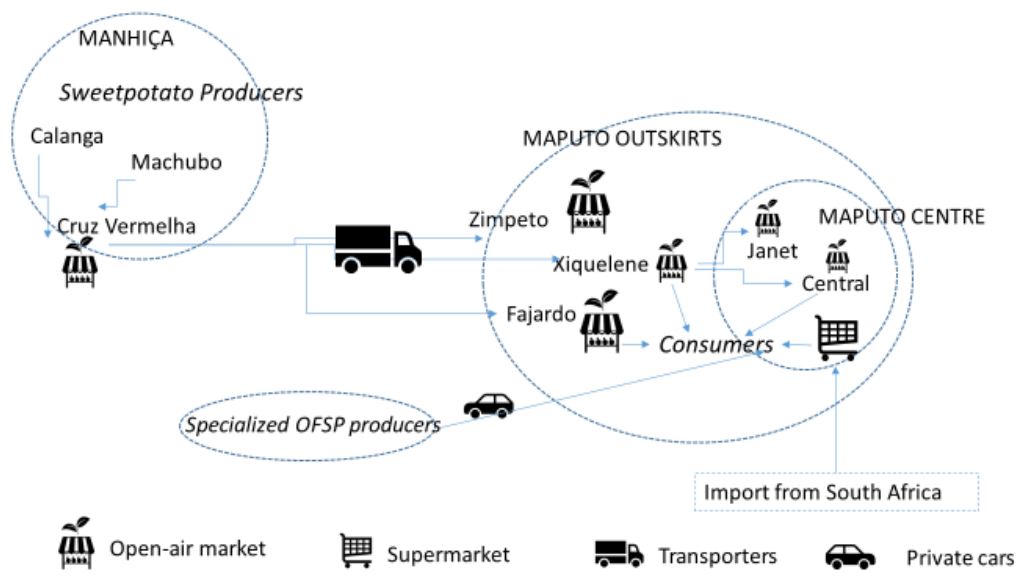

Figure 1. Overview of the organization of the sweetpotato commodity chain 


\subsection{Actors}

The sweetpotato commodity chain is characterized by different types of actors. The non-orange-fleshed varieties chain consists basically of four groups: producers, transporters, traders and consumers (Figure 2).

Producers can both consume and sell their produce. They typically sell fresh roots (a) at the farm gate to local consumers or visiting traders, (b) at village markets to local consumers or to traders, or (c) they may carry their crop to a bulking market such as the Cruz Vermelha in Manhiça town. They do not process the sweetpotato roots.

Traders are subdivided in three categories: (a) those who buy at the farm gate and/or bulking markets in the production area and sell at wholesale or retail markets in the urban area; (b) those who buy at wholesale markets and sell at retail markets or sidewalks to consumers; and (c) shops or supermarkets selling sweetpotato.

Most producers and traders do not possess their own means of transport. Transporters provide that service (i.e. owning or driving a tractor, truck, or minibus, or simply carrying bags with their hands and heads) and they do not themselves buy or sell roots. Transport may be from the field to the bulking market at district level, from the market to the trucks and lorries parked outside, from the bulking market to the urban wholesale or retail market.

Consumers can be classified as (a) producer-household members; (b) producer-community members; (c) urban residents shopping at wholesale markets; (d) urban residents shopping retail markets or street corners; (e) urban resident buying from specialized OFSP producers; and (f) urban residents buying at supermarkets.

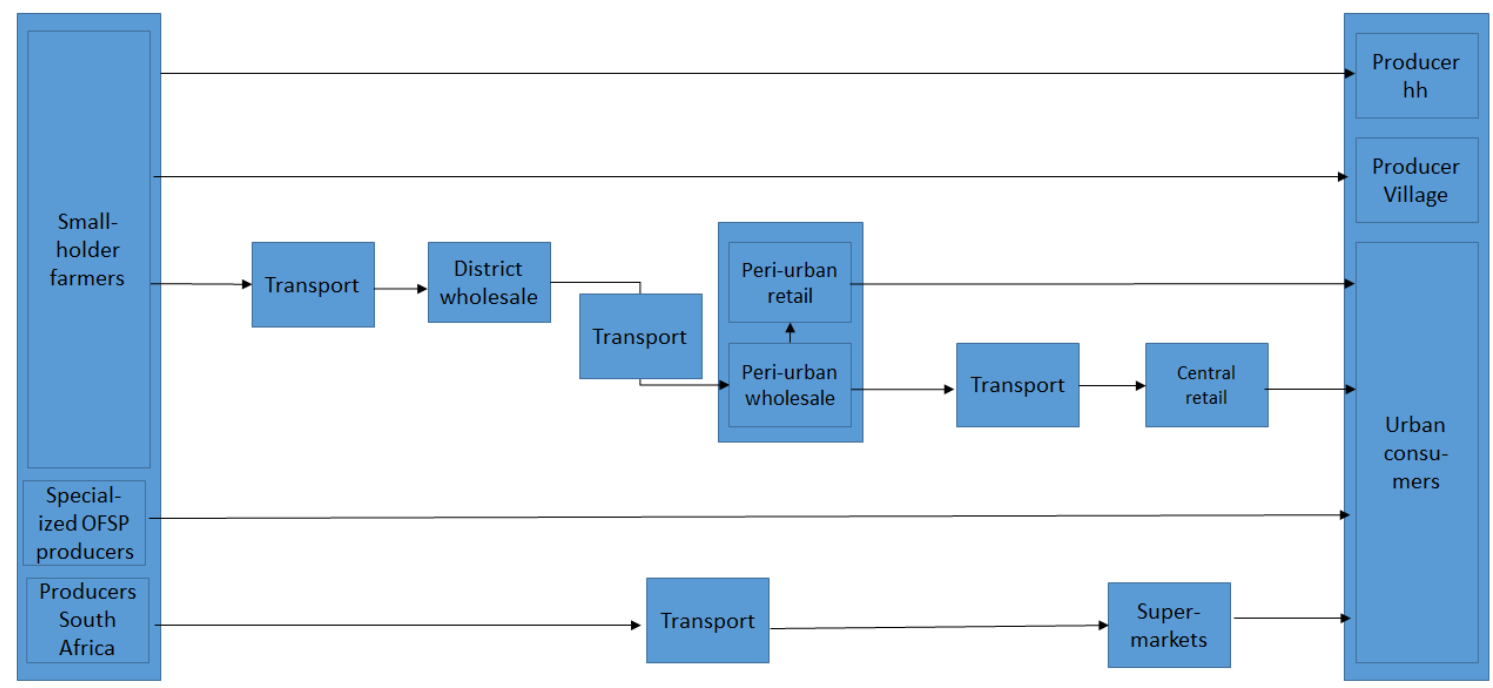

Figure 2. Flowchart of the sweetpotato commodity chain in the research areas

Producers of non-orange-fleshed sweetpotato varieties obtain planting material by maintaining vines from the previous harvest. People share vines with neighbours as part of a mutual risk assurance (Jenkins, Byker Shanks, Brouwer, \& Houghtaling, 2018). Occasionally, producers may also buy vines.

In the case of orange-fleshed variety, CIP provides basic planting material to selected vine multipliers. CIP (and other agencies) buys multiplied material from these multipliers at a standard price for distribution. Distribution prioritizes households with pregnant or lactating women, infants or pre-school children as main target groups for VAD combating strategy.

The numbers of people involved along the chain can only be estimated. Manhiça district has 20,741 rural households; 2,330 live in the Calanga area where production is concentrated (Instituto Nacional de Estatística [INE], 2010). On average 15\% of the farmers grow white-fleshed and $4 \%$ orange-fleshed (Ministry of Agriculture [MINAG], 2012). Field observations and interviews with residents have shown that in Calanga there are no farmers growing exclusively orange-fleshed varieties. Thus, it is safe to state that in Calanga alone there are about 350 sweetpotato producers whereof about one-third also cultivate OFSP.

Farmers in Calanga rely on a tractor to transport the crop from the producing communities to the market. The transport is charged by bag and by passenger. Transport to Maputo is assured by up to thirteen lorries - the number of cars varies with supply - with a capacity of three to five tonnes each, and by some pick-ups and minibuses that can carry less than a tonne. Lorries will typically carry bags for several traders. Some traders pool procurement. Thus, the total number of traders will be around 40 to 50 . 
The gendered nature of the commodity chain is striking: almost all producers and traders are female. The carrying, and on and off loading of bags and driving of tractors, lorries and minibuses is exclusively done by men.

\subsection{Volumes - Supply}

The population of Maputo City gets its sweetpotato from two sources: local production and importation from the surrounding districts. Maputo is a big city of about 1.2 million inhabitants (INE, 2010). Despite its urban character many of its residents have access to land. Data collected by CIP in 2014 indicate that about $24 \%$ of the city's population grows sweetpotato.

The Manhiça bulking market operates three times a week (Monday, Wednesday and Friday), between 6 and 8 am. There are no official data on the traded volume. As a result, all volumes were estimated.

Sweetpotato wholesale is typically done in bags. One bag weighs around $65 \mathrm{~kg}$ (International Potato Centre [CIP] Monitoring, 2016). One count by the authors in July 2016 of the bags for sale and the trucks ready for transport indicated that on that day more than 20 tons were traded. With three market days per week trade per year would amount around 3,000 tonnes.

At the request of the authors the Manhiça Municipality recorded sweetpotato sales over a three-weeks period in 2016. Their count suggests an annual turn-over of about 4,000 tonnes, which is in the same ballpark as the earlier estimate. With Manhiça supplying 40-50\% of total supply Maputo consumers buy between 6,000 and 10,000 tons of sweetpotato per year.

Manhiça Municipality was asked also to register bags by root colour. They found that about two-thirds of the bags contained only white-fleshed roots and one-third of the bags was filled with a mixture of white and orange-fleshed roots. They did not register any bags with only orange-fleshed varieties. The collected data do not allow the proportions of white and orange-fleshed roots to be estimated. They suggest that OFSP represents less than one-third of all sweetpotato; they confirm that at the level of Manhiça wholesale market the value chains of both types are almost fully intertwined. Some retailers interviewed in the market by the lead author said that some OFSP is sold in separate bags.

The specialized OFSP producers from Boane do not sell through the chain but directly to clients who come to visit their roadside stalls or through home delivery. Their market share is small. The largest operates an irrigated area of 1 hectare; others farm areas with less than $1000 \mathrm{~m}^{2}$. Given the acreage the contribution of this group to the market is limited to between 40 and 80 tonnes per year. This is about $0.5 \%$ to $1 \%$ of the entire sweetpotato market and about $1.5 \%$ to $3 \%$ of the market for OFSP.

The main supermarkets rely fully on import from South Africa. Interviews with stock managers of two important stores indicate that they sell about 10 tonnes of white-fleshed roots per year. According to the Department of Agriculture, Forestry and Fisheries of the Republic of South Africa (2012) in 2011 total sweetpotato exports from South Africa to Mozambique amounted about 10 tonnes at US\$ 8,000. FAOSTAT (2016) estimates Mozambique's imports at US\$ 16,000 for 2013. The share of imported roots is small. If all imports end up in Maputo City, they represent less than $0.2 \%$ of the total 8,000 tonnes of sweetpotato which passes through the Maputo market.

\subsection{Volume - Demand}

Table 1 shows that $30 \%$ of consumers eat sweetpotato less than once a month and two-thirds $(65 \%)$ less than once a week. A considerable percentage (25\%) eat sweetpotato almost every day. These are results from the 2014 survey among pedestrians at over 40 locations dispersed over Maputo City. They show the sum of the product of the central values of the number of meals per year and the percentage of the respondents in each frequency category estimates the average number of meals with sweetpotato eaten by all respondents at 114 per year. Assuming a (conservative) mean consumption of $0.1 \mathrm{~kg}$ per person per meal and considering then Maputo's whole population, this results in an annual urban consumption of about 14,000 tonnes.

One way to check the validity of this estimate is to cross it with information from other sources. Part of Maputo's sweetpotato consumption is satisfied by what people cultivate in their own gardens and plots. Unpublished IAI data for 2015 indicate that there are about 346 hectares of sweetpotato inside Maputo City (pers. comm. Benedito Gunguara, Michigan State University). Using the FAOSTAT (2016) and GPM (2013) yield estimates, this means that between 5,000 and 6,400 tonnes come from people's own fields. Summing this value to the supply of about 8,000 tonnes sold on the market the city total consumption is indeed about 14,000 tonnes. 
Table 1. Frequency with which sweetpotato in general and OFSP in particular according to the results of the Maputo survey $(\mathrm{n}=656)$.

\begin{tabular}{|c|c|c|c|c|c|}
\hline \multirow[b]{2}{*}{ Share of OFSP within meals } & \multicolumn{4}{|c|}{ Number of meals with white and/or orange-fleshed SP } & \multirow[t]{2}{*}{ Total } \\
\hline & $\begin{array}{l}\text { Less than one } \\
\text { per month }\end{array}$ & $\begin{array}{l}\text { Up to one } \\
\text { per week }\end{array}$ & $\begin{array}{l}\text { Up to one } \\
\text { per day }\end{array}$ & $\begin{array}{l}\text { More than } \\
\text { one per day }\end{array}$ & \\
\hline Less than one third & $25 \%$ & $22 \%$ & $16 \%$ & $5 \%$ & $67 \%$ \\
\hline Less than two thirds & $3 \%$ & $8 \%$ & $4 \%$ & $2 \%$ & $17 \%$ \\
\hline More than two thirds but not all & $2 \%$ & $5 \%$ & $5 \%$ & $3 \%$ & $14 \%$ \\
\hline All & $0 \%$ & $1 \%$ & $0 \%$ & $0 \%$ & $2 \%$ \\
\hline Total & $30 \%$ & $35 \%$ & $25 \%$ & $9 \%$ & $100 \%$ \\
\hline $\begin{array}{l}\text { Central value of the \# of meals } \\
\text { per year in each category }\end{array}$ & 6 & 32 & 209 & $547^{\mathrm{a}}$ & $114(31 \%)$ \\
\hline
\end{tabular}

In each column Table 1 shows the frequency of meals with OFSP. Repeating the same calculation but now weighted for the stated shares with OFSP it appears that less than one-third (31\%) of all sweetpotato meals contains OFSP. Overall, those who eat OFSP eat it about once in two weeks.

It should be noted that OFSP is not always a conscious choice: as farmers may mix varieties in their bags, many people eat OFSP only by chance. On the other hand, people who try to buy orange-fleshed varieties may find that they bought white-fleshed roots: of the 131 samples sold to CIP as orange-fleshed over 2014/15, $12 \%$ contained both colours and 7\% contained only white-fleshed varieties.

As those who eat OFSP may consume it in combination with white-fleshed roots it is not possible to estimate the share of either type.

\subsection{Pricing}

Sweetpotato root prices vary according to season, market or selling location, quality and size of the roots (with larger roots fetching a higher per kilo price than the smaller ones), the colour of skin and flesh. It should be noted that calculating costs and revenues along the chain is difficult as people use different volume-based units (e.g. bags, basins, buckets and piles), as opposed to weight-based units. Wholesale is normally in $50 \mathrm{~kg}$ "Babita" wheat flour bags but the real weight of a fully packed sweetpotato bag can be more than $70 \mathrm{~kg}$. On average, full bags weigh about $65 \mathrm{~kg}$. Retailing is per basin (about $20 \mathrm{~kg}$ ), bucket (about $15 \mathrm{~kg}$ ), or pile (between 1 and $3 \mathrm{~kg}$ ) (CIP Monitoring, 2016).

Semi-structured interviews of sweetpotato producers in Manhiça indicate a price variability of more than $100 \%$ between peak and low season; these farmers obtain a premium price for bigger roots but not for OFSP. According to traders who were interviewed on various markets, buying prices fluctuate more than selling prices. Traders' confirm that their buying prices can vary more than 100\%. Retailers in Mercado Janet report that they buy bags at 350 MT (US\$10, as of April 2015 one dollar was worth 35 MT approx.) during the main season, but prices may reach 1,000 MT (US\$28) when the supply is low; at the retail market in Manhiça Town, a bucket can fetch 150 MT (US\$ 4.5) and 350 MT during the high and low supply season, respectively. Variation in selling price of bags and buckets between the peak and low supply seasons are instead between $25 \%$ and $66 \%$. The highest variation is reported for the prices per kilo at Mercado Janet and the price of piles of small roots at Mercado Xiquilene. This suggests that, along the commodity chain, retailers are the actors bearing the main cost of the seasonal variation in price. They may hide the variation in price per kilo by how they build their piles, fill basins, buckets and bags, for example filling a bag or piling a pile with less roots during the low supply season. 


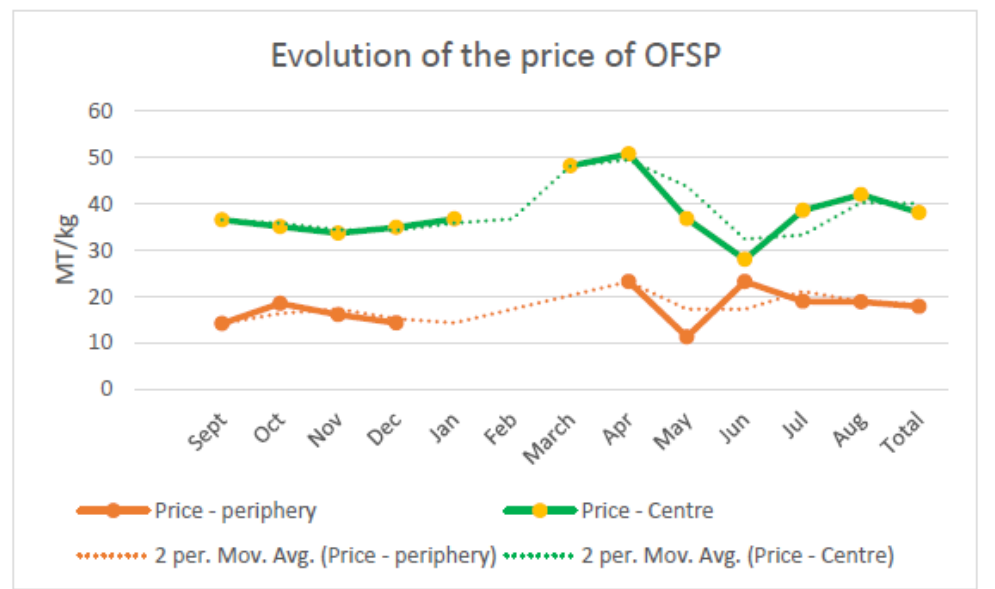

Figure 3. Evolution of the average price of roots on peripheral and central markets in Maputo between September 2014 and August 2015 (source: data collected by CIP). 2 per. Mov. Avg.= data points calculated on averages over two periods

Figure 3 also indicates that the location matters. Per kg prices at markets in the city centre are approximately 20 Meticais higher than those in the periphery. At urban markets the average price per kg was $38.09 \mathrm{MT}$ against 17.86 MT at the peri-urban markets (periphery). This difference is statistically significant. The price difference explains the role of peripheral markets as an intermediary source of roots between the production area and the markets in the city centre combining retail and wholesale activities.

Figure 3 shows also how retail prices vary during the year, rising from January to April and declining again in June. The difference between the lowest and the highest average price in the peripheral market was $12 \mathrm{MT} / \mathrm{kg}$ (67\% of the annual mean), while in the markets in the city centre it was $23 \mathrm{MT} / \mathrm{kg}$ (60\% of the annual mean).

Prices are also influenced by the size of the roots, with bigger roots being more expensive than smaller ones although this correlation is not statistically significant at $5 \%$.

Skin colour also influences price. During the second semester of 2014, SIMA collected on behalf of CIP 860 price samples from six markets (five peripheral and one in the centre). These samples show that light-skinned varieties fetch a higher price than the darker-skinned ones. They also indicate that there is no significant difference in price between the white and orange-fleshed varieties from July till November. In December orange-fleshed varieties were 50\% more expensive than white-fleshed. However, subsequent visits to market and retailers have confirmed that there is in general no bonus for orange-fleshed roots (Figure 4).

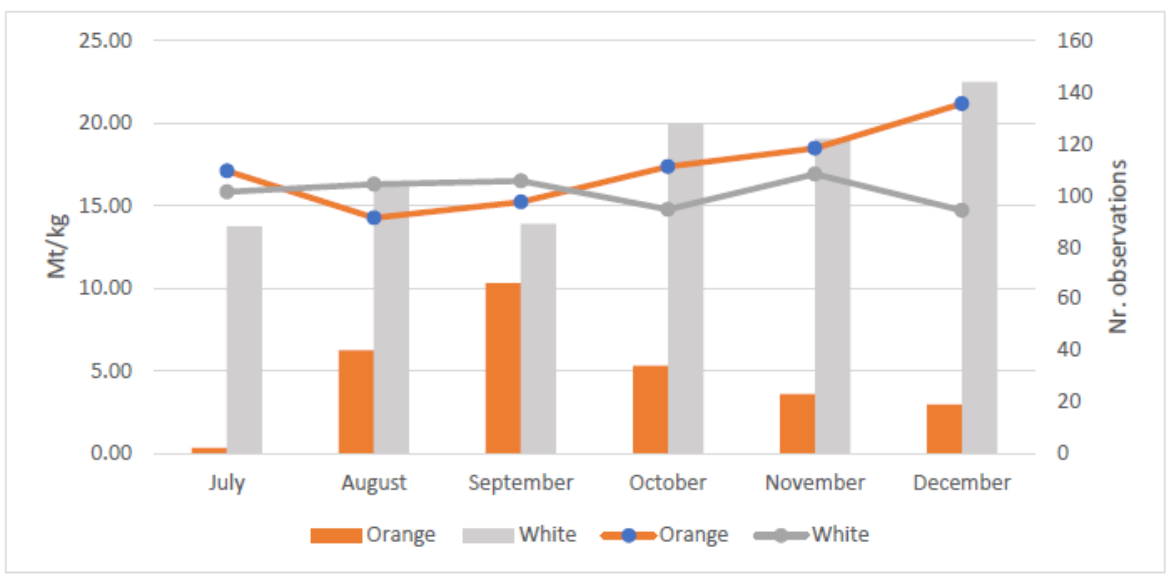

Figure 4. Comparison of OFSP and SP root retail prices between July and December 2014 in Maputo. Source: Data collected by SIMA on behalf of CIP on Maputo markets (lines: prices; bars: numbers of observations)

The lack of a premium price for OFSP matches with the observed practice of producers mixing varieties and flesh colours indiscriminately. 
Whereas in general there is no bonus for orange-fleshed roots there is a market segment that is willing to pay more for these biofortified varieties. The specialized OFSP farmers in Boane, as mentioned earlier, exploit this business opportunity practicing prices that are considerably higher than what their fellows in Manhiça manage to fetch. They can do this because of a network of known clients buying at prices between 25 and $30 \mathrm{MT} / \mathrm{kg}$ all year round.

\subsection{Costs and Revenues along the Chain}

The study did not collect data about costs and revenues from a representative sample of those involved in the value chain. It did carry out individual and group interviews of farmers and retailers to obtain insights in the profitability of sweetpotato production and the distribution of costs and revenues along the chain.

The revenues at the production level are dependent on scale, business orientation, access to inputs such as irrigation, and location.

A group of about fourteen smallholder farmers selling white-fleshed sweetpotato in Manhiça explained they had no production costs as they neither use inputs such as fertilizer nor hire labour. Their association covered the cost of land preparation. Their only costs were related to trading. They paid 25 MT per bag to transport fresh roots from their field into the market. At the market, they paid to the municipality a daily tax of 20 MT and 6.5 MT per bag for cleaning. If a bag weighs about $65 \mathrm{~kg}$ their costs amounted about $0.8 \mathrm{MT} / \mathrm{kg}$. They sold the roots three days a week during the harvest period that can last from three to over six months. At the beginning of the season and when the sweetpotato supply is very low, the selling price can reach 600 MT per bag, i.e. about 5.4 MT per $\mathrm{kg}$. In this case, the gross margin amounts to about $85 \%$ of the revenues.

Further down the chain, onward transport costs from Manhiça to the Greater Maputo area were a further 30-50 MT/bag. The transport cost from the peripheral/wholesalers markets to those in the city centre were another 50 MT/bag.

Five farmers specializing in OFSP root production for the market were interviewed individually. All said they had access to irrigation and hired labour. The largest even had a tractor. They reported profits between 214,000 and 605,000 MT per ha/annum. The upper value may be an overestimation. This farmer reported a yield of 30 tonnes/ha, i.e. 1.5 times the yield estimated by Tumwegamira et al. (2013), 1.6 times the estimate by FAOSTAT (2016) and double the one by the Government of the Province of Manica (GPM, 2013). These farmers don't use intermediaries but sell directly to consumers at a premium price of $30 \mathrm{MT} / \mathrm{kg}$.

Table 2 contains a summary of costs and revenues along the chain between Manhiça and Maputo. Selling and buying prices are reported for the peak (lower value) and low supply (higher value) season, along with the number of bags sold per week (with the lowest number corresponding to the low season). The calculations of the profits may not fully include the market fees, taxes, and other lump-sum payments as these are paid per day and not per bag or service that often includes also other agricultural commodities traded.

The interviewed retailers located in the urban markets of Maputo sell white-fleshed and orange-fleshed sweetpotato at 30-50 MT/kg depending on the season and the flesh colour. It is difficult to estimate exactly their profits as they buy bags of unknown weight, and prices and quantity are subjected to seasonality. Assuming standard weights, gross revenue can be up to $1,650 \mathrm{MT} / \mathrm{bag}$ and their gross margin is between 15 to $26 \mathrm{MT} / \mathrm{kg}$ (about $45 \%$ of the average gross revenue), which is among the highest margins of all actors along the chain in Maputo area.

The calculation of the margins for the retailers located in the peri-urban markets in Maputo and Manhiça is more difficult as the retailers buy by bucket or bag, and then sell the roots on in bags, buckets, and piles without weighing them. An average margin per bag is estimated at 250-550 MT during the peak supply season and 350-700 MT during the low supply season corresponding approximately to 1.5 MT per kg in Mercado Xiquilene up to $8 \mathrm{MT}$ per kg in Manhiça. Although retailing activities appears to be the more profitable in urban markets, volumes are higher in the peri-urban and rural markets. 
Table 2. Key costs along the commodity chain for SP (July 2015)

\begin{tabular}{|c|c|c|c|c|c|c|}
\hline $\begin{array}{lr}\text { Type } & \text { and } \\
\text { location } & \text { of } \\
\text { market } & \end{array}$ & $\begin{array}{l}\text { Source of } \\
\text { information }\end{array}$ & $\begin{array}{l}\text { Selling price } \\
\text { (in MT) } \\
\text { (on average) }\end{array}$ & $\begin{array}{l}\text { Overall } \\
\text { transport } \\
\text { costs } \\
\text { (in MT) }\end{array}$ & $\begin{array}{l}\text { Market fees, } \\
\text { taxes and } \\
\text { services (in } \\
\text { MT)* }\end{array}$ & $\begin{array}{l}\text { Buying } \\
\text { price (in } \\
\text { MT) } \\
\text { (on } \\
\text { average) } \\
\end{array}$ & $\begin{array}{l}\text { Profits }= \\
\text { Selling price - } \\
\text { costs (in MT) } \\
\text { (on average) }\end{array}$ \\
\hline $\begin{array}{l}\text { Wholesale, } \\
\text { rural, } \\
\text { producers, } \\
\text { Manhiça }\end{array}$ & $\mathrm{A}, \mathrm{n}=14$ & $\begin{array}{l}150 \text { to } 600 \text { per } \\
\text { bag, } 2.5 \text { to } 10 \\
\text { MT per Kg }\end{array}$ & $\begin{array}{l}25 \text { per bag } \\
\text { (tractor) }\end{array}$ & $\begin{array}{l}26.5 \text { per bag } \\
\text { per day }\end{array}$ & 0 & $\begin{array}{l}198.5 \text { to } 48.5 \\
\text { MT per bag or } \\
1.5 \text { to } 9 \mathrm{MT} \\
\text { per kg. }\end{array}$ \\
\hline $\begin{array}{ll}\text { Retail, } & \text { rural } \\
\text { Manhiça } & \end{array}$ & $\mathrm{B}, \mathrm{n}=1$ & $\begin{array}{l}12 \text { per } \mathrm{kg}^{\wedge} \\
\text { (approx.) }\end{array}$ & 10 per bag & $\begin{array}{l}5 \text { per day } \\
(2-9 \quad \text { bags } \\
\text { sold per } \\
\text { week })\end{array}$ & $\begin{array}{l}150 \text { to } 250 \\
\text { per bag; } \\
2-4 \text { per } \mathrm{kg} \\
\text { (approx.) }\end{array}$ & $7-9$ per kg \\
\hline $\begin{array}{l}\text { Mixed, } \\
\text { peri-urban } \\
\text { Mercado } \\
\text { Zimpeto, } \\
\text { Maputo }\end{array}$ & $\mathrm{B}, \mathrm{n}=1$ & $\begin{array}{l}150 \text { to } 250 \text { per } \\
\text { bucket, } 10-17 \\
\text { per } \quad \mathrm{kg} \\
\text { (approx.) }\end{array}$ & $\begin{array}{l}150 \text { per bag } \\
2 \text { per } \mathrm{kg} \\
\text { (approx.) }\end{array}$ & $\begin{array}{l}55 \text { per day } \\
(8-40 \\
\text { buckets sold } \\
\text { per week) }\end{array}$ & $\begin{array}{l}60 \text { to } 200 \\
\text { per bucket } \\
4-13 \text { per } \\
\mathrm{kg} \\
\text { (approx.) }\end{array}$ & $\begin{array}{l}3.5-11.5 \text { per } \\
\mathrm{kg}\end{array}$ \\
\hline $\begin{array}{l}\text { Retail, } \\
\text { Peri-urban } \\
\text { Mercado } \\
\text { Xiquilene }\end{array}$ & $\mathrm{B}, \mathrm{n}=1$ & $\begin{array}{l}10 \text { to } 15 \text { per } \\
\mathrm{kg} \text { (approx.) }\end{array}$ & $\begin{array}{l}10 \text { per bag } \\
0.5 \text { per } \mathrm{kg} \\
\text { (approx.) }\end{array}$ & $\begin{array}{l}8 \text { per day } \\
(1-4 \quad \text { bags } \\
\text { sold per } \\
\text { week })\end{array}$ & $\begin{array}{l}500 \text { to } 800 \\
\text { per bag } \\
7-12 \text { per } \\
\text { kg } \\
\text { (approx.) }\end{array}$ & 2 per kg \\
\hline $\begin{array}{l}\text { Mixed, } \\
\text { peri-urban, } \\
\text { Mercado } \\
\text { Fajardo }\end{array}$ & $\mathrm{B}, \mathrm{n}=2$ & $\begin{array}{l}600 \text { to } 800 \text { per } \\
\text { bag } \\
9-12-\text { per } \mathrm{kg} \\
\text { (approx.) }\end{array}$ & $\begin{array}{l}50 \text { per bag } \\
1 \text { per kg } \\
\text { (approx.) }\end{array}$ & $\begin{array}{l}35 \text { per day } \\
(3-20 \quad \text { bags } \\
\text { sold per } \\
\text { week })\end{array}$ & $\begin{array}{l}200 \text { to } 500 \\
\text { per bag } \\
3-8 \text { per } \mathrm{kg} \\
\text { (approx.) }\end{array}$ & $3-5$ per $\mathrm{kg}$ \\
\hline $\begin{array}{l}\text { Retail, urban } \\
\text { Mercado Janet }\end{array}$ & $\mathrm{B}, \mathrm{n}=2$ & $\begin{array}{l}30 \text { to } 50 \text { per } \\
\mathrm{kg} \\
\text { (OFSP) }\end{array}$ & $\begin{array}{l}75 \text { per bag } \\
1 \text { per } \mathrm{kg} \\
\text { (approx.) }\end{array}$ & $\begin{array}{l}25 \text { per day } \\
(20-20 \quad \mathrm{~kg} \\
\text { sold } \\
\text { week })\end{array}$ & $\begin{array}{l}150 \text { to } 350 \\
\text { per bucket } \\
10-23 \text { per } \\
\mathrm{kg} \\
\text { (approx.) }\end{array}$ & $19-26$ per kg \\
\hline $\begin{array}{l}\text { Retail, urban, } \\
\text { Mercado } \\
\text { Central }\end{array}$ & $\mathrm{B}, \mathrm{n}=2$ & $\begin{array}{l}40 \text { to } 50 \text { per } \\
\mathrm{kg} \\
\text { (OFSP) }\end{array}$ & $\begin{array}{l}100 \text { per bag } \\
1.5 \text { per kg } \\
\text { (approx.) }\end{array}$ & 9 per day & $\begin{array}{l}1,500 \text { to } \\
1,650 \text { per } \\
\text { bag } \\
23-25 \text { per } \\
\mathrm{kg} \\
\text { (approx.) }\end{array}$ & $15-23$ per $\mathrm{kg}$ \\
\hline
\end{tabular}

Note: *These costs are not always included in the profit calculation as it is difficult to convert them in per $\mathrm{kg}$ values, considering that they are per day, or they include the trade of other commodities. Numbers are rounded to the next digit. ^The retailer sells in small bags or piles. The price of bags or piles may not vary seasonally but it varies their size/weight.

$\mathrm{A}=$ Group semi-structured interview

$\mathrm{B}=$ Individual semi-structured interview 


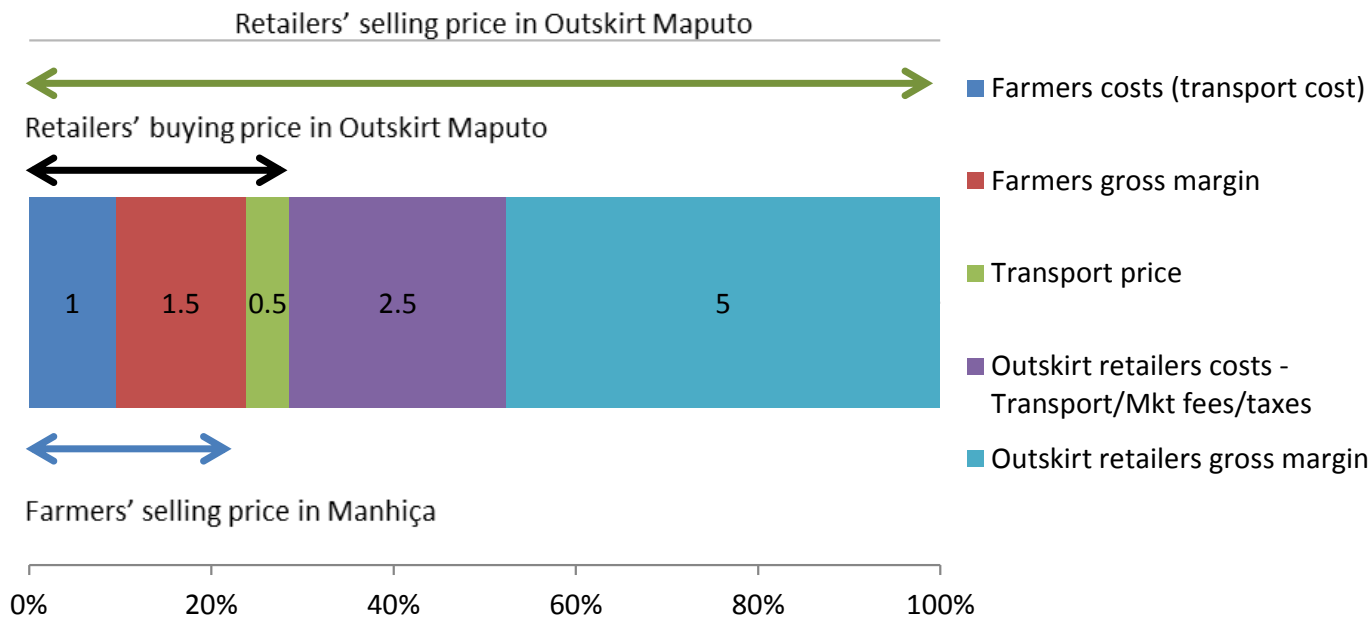

Figure 5. Allocation of revenues from selling sweetpotato along the chain during peak season (in $\mathrm{MT} / \mathrm{kg}$ )

Source: Authors' elaboration considering farmers' selling price of $150 \mathrm{MT} / \mathrm{bag}$ in Manhiça, retailers' market in Zimpeto with the buying cost of $60 \mathrm{MT} / \mathrm{bucket}$ and volume sold of 8 bucket/day (market fees, taxes and services amount to $0.5 \mathrm{MT} / \mathrm{kg}$ ). Transport price is calculated as difference between retailers' buying price and farmers' selling price

The distribution of revenues along the white-fleshed sweetpotato value chain for the producers, transporters and traders selling roots at markets in the peripheral area of Maputo City is shown in Figure 5. In the case of fresh roots coming from Manhiça, farmers' and retailers' gross profits represent respectively $15 \%$ and up to $45-50 \%$ of the price paid by the consumers (10 MT/kg approx.). In this case, retailers' gross margins per kilo are higher than those of farmers. The incomes each agent obtains depend not only on the margin but also on turnovers.

\subsection{Governance}

The government's role in the sweetpotato value chain is limited to applying taxes and fees. There is no control on scales, weights and prices as almost all markets sales are not per weight unit but per bag, bucket, or pile. The only markets where roots are sold per kg are Mercado Central and Mercado Janet.

The Ministry of Agriculture publishes each week commodity prices across the country to increase market transparency. The prices are per city and include sweetpotato. The research did not assess whether this information was used by any of the agents in the chain.

Interviews with smallholders from Manhiça confirm that support from agricultural extension services to producers is limited (Mubai, 2014) and that there is no institutionalized control of quality along the chain.

\section{Discussion}

The sweetpotato commodity chain in Mozambique is focused entirely on fresh roots. Contrary to what was found by Mmasa and Msuya (2012), farmers do not process their roots; processing is done by the final consumers.

While Mmasa, Msuya and Mlambiti (2013) highlight the opacity of the market in Tanzania due to the lack of transparency regarding prices, units and quality demands, in Mozambique the Ministry of Agriculture publishes consumer market prices in its weekly SIMA market bulletin. But as these prices are per kilo and trade is in roughly standardized volume units such as bags, basins, buckets and piles, transparency remains limited with ample room for manipulating per kg prices. Another aspect not covered by SIMA are that market women sort roots by size to cater for different market segments and to maximize the revenue of a mixed supply.

Degu, Uragie, Zeberga, Musemil, and Adane (2015) observed that in Ethiopia margins increase moving along the chain from the farmers to the retailers. The data summarized in Figure 5 suggest that the same happens in Mozambique but the number of observations is too small to make any solid quantitative affirmation.

Gendered obstacles do not appear to prevent women's participation in the sweetpotato chain in Mozambique. In Papua New Guinea women only participated in the production stages (Chang \& Kewa, 2014). In Mozambique, women participate as producers, sellers, traders and buyers in the wholesale and retail markets while the role of men is almost completely restricted to transport. 
In Kenya brokers are actively involved in purchasing of sweetpotato roots from farmers and organising their transport to wholesale traders in the large urban markets (Tedesco \& Stathers, 2015). Around Maputo there are no intermediaries. A relatively large group of producer-sellers meet a relatively large group of buyer-traders. It is therefore difficult to say whether this value chain (filière) is seller or buyer dominated (Raikes, Jensen, \& Ponte, 2011). Farmers feel they are in a weaker position as they incur numerous costs to get their produce to the market and then face the risk of not finding clients. They claim that they try and set a minimum price but that usually one of the farmers feels too much (time) pressure and breaches the agreement of the group and sells the roots below the agreed value. They also suspect that the traders try and fix a price. The traders who come to the market incur costs and face risks, too. They may not find the quantity and quality of roots they need. Like the producers, traders feel pressure as they lose selling time when they delay their departure to the city or may even lose their transport opportunity. In the city, they may be unable to sell their stocks to consumers. Finally, retailers appear unable to fully transmit price variation to the consumers.

In Kenya, OFSP receives an extra push from processing. Tedesco and Stathers (2015) found that OFSP is processed into OFSP flour or a composite flour and incorporated into processed products. In Maputo processing is incipient. Since 2016 two bakers process about 1.5 tonnes of roots per month to make OFSP bread. If these efforts are successful, the marketing of roots for processing may become an important addition to the commodity chain but the current amount represents only $0.2 \%$ of total sweetpotato consumption. With OFSP representing less than one third of that market, these bakers consume about $0.7 \%$ of all OFSP, probably still too small to have a significant impact.

\section{Conclusions and Recommendations}

This paper aims to understand the specific characteristics of the sweetpotato value chain and which factors influence the presence (or the absence, in this case) of OFSP roots in urban markets. This investigation is done identifying actors and main activities, establishing size of traded volumes, and mapping the distribution of costs and benefits along the chain.

The study shows that the chain consists of producers, traders, transporters and consumers. It covers a range of about $70 \mathrm{~km}$ around Maputo City. About one-third of smallholders producing sweetpotato also produce OFSP. The city consumes about 14,000 tonnes of sweetpotato per year, but as many residents grow their own roots, only about 8,000 tonnes are bought at the market.

The smallholders in Manhiça producing orange-fleshed do normally not separate by colour. A small group of resource rich farmers target clients who are specifically interested in OFSP. This segment is very small (about 0.5 to $1 \%$ of the entire sweetpotato market) and covers the wealthier consumers.

Outlets of the large supermarket chains do not influence sweetpotato farming around Maputo. They import their white-fleshed roots from South Africa and their share is less than $0.2 \%$ of the total market.

The Government's role is limited to taxation and creating (minimal) infrastructures for trading. It also publishes market prices, but it is unclear whether these play any role in the way the market is operated. CIP plays an important role in supplying producers with OFSP planting material to increase the percentage of sweetpotato acreage dedicated to these cultivars.

This value chain study has successfully identified why OFSP does not meet current demand. We find that OFSP does not constitute a separate strand in the commodity chain meaning that, although seemingly profitable, the orange-fleshed roots remain shackled to the existing chain. There is no specific financial stimulus for producers to increase the acreage of the biofortified crop, and information on the profitability of such crop seems not to reach the producers or not to be sufficiently convincing to make them change their production plans. Until a positive specific upstream feedback loop is established, the expansion of supply will depend on the competitiveness of these varieties starting at the farmer level. Farmers are more worried about a variety's yield than its nutrition value. Unless the biofortified cultivars can outcompete the traditional white-fleshed ones in terms of yield, the share of OFSP in the market will not grow.

\section{Acknowledgements}

The authors are grateful to the Bill \& Melinda Gates Foundation in Seattle and the Department for International Development of the United Kingdom for the support to the International Potato Centre (CIP) which made this study possible. A special word of gratitude is directed to Jan Low (CIP) for establishing the bridge between these two projects and encouraging this study, and to Tanya Stathers (NRI) for commenting on a previous version. Finally, they wish to recognise the effort of the enumerators and market monitoring staff who interviewed consumers and collected the price data that have allowed for a quantitative underpinning of this study. 


\section{Declaration of interest}

The authors declare that there is no conflict of interest.

\section{References}

Demment, M. W., Youngy, M. M., \& Sensenig, R. L. (2003). Providing Micronutrients through Food-Based Solutions: A Key to Human and National Development. The Journal of Nutrition, 133(11), 3879S-3885S. https://doi.org/10.1093/jn/133.11.3879S

Blasbalg, T., Wispelwey, B., \& Deckelbaum, R. (2011). Econutrition and utilization of food-based approaches for nutritional health. Food and Nutrition Buletim, 32(1), suppl1, S4-S13. https://doi.org/10.1177/15648265110321S102

Brito, L., Brouwer, R., \& Falcão, M. (2012). Sweetpotato-Biotechnology in different guises on a broad range of scales. Technological Forecasting \& Social Change, 79(2), 204-212. https://doi.org/10.1016/j.techfore.2011.11.006

Chang, H.-S. C., \& Kewa, J. (2014). Sweetpotato value chain analysis in Papua New Guinea. Conference paper presented to the 8th ASAE Conference, Savar, Bangladesh, 15-17-2014. Retrieved from https://www.une.edu.au/_data/assets/pdf_file/0017/104516/2014-Sweetpotato-value-chain-analysis-in-PN G.pdf

CIP Monitoring, L. A. (2016). Tools and Techniques for Monitoring Key Indicators of Sweetpotato Interventions in Sub-Saharan Africa: A Practitioner's Manual (Unpublished). International Potato Centre (CIP), Nairobi, Kenya .

Coase, R. (1937). The nature of the firm. Economica, 4(16), 386-405. https://doi.org/10.1111/j.1468-0335.1937.tb00002.x

Degu, G., Uragie, E., Zeberga, A., Musemil, S., \& Adane, T. (2015). Sweet Potato Market Chain Analysis: The Case of SNNPR, Ethiopia. Greener Journal of Agriultural Science, 5(7), 240-264. http://doi.org/10.15580/GJAS.2015.7.072513755

Department of Agriculture, Forestry and Fisheries Republic of South Africa. (2012). A profile of the South African Sweet Potato market Value Chain. Retrieved from http://www.nda.agric.za/docs/AMCP/SWEET2012.pdf

FAOSTAT. (2016, November 15). In FAOSTAT. Retrieved from http://faostat3.fao.org/download/Q/QC/E

GPM. (2013). Plano Económico e Social - 2013. Chimoio: Governo da Província de Manica.

INE. (2010). III recenseamento geral da população e habitação, 2007 : resultados definitivos. Maputo: Instituto Nacional de Estatística.

Jenkins, M., Byker Shanks, C., Brouwer, R., \& Houghtaling, B. (2018). Factors affecting farmers' willingness and ability to adopt and retain vitamin A-rich varieties of orange-fleshed sweet potato in Mozambique. Food Security, 10(6), 1501-1519. https://doi.org/10.1007/s12571-018-0845-9

Low, J., Arimund, M., Osman, N., Gunguara, B., Zano, F., \& Tschirley, D. (2007). A Food-Based Approach Introducing Orange-Fleshed Sweet Potatoes Increased Vitamin A Intake and Serum Retinol Concentrations in Young Children in Rural Mozambique. The Journal of Nutrition, 137(5), 1320-1327. https://doi.org/10.1093/jn/137.5.1320

MASA. (2015). Anuário de Estatísticas Agrárias 2012-2014. Maputo: Ministério da Agricultura e Segurança Alimentar. Retrieved from http://fsg.afre.msu.edu/Mozambique/survey/Anuario_Estatistico_2012_2014_Final.pdf

MINAG. (2012). Trabalho de Inquerito Agricola 2012. Maputo: Ministário da Agricultura.

Minegishi, S., \& Thiel, D. (2000). System dynamics modeling and simulation of a particular food supply chain. Simulation Practice and Theory, 8(5), 321-339. https://doi.org/10.1016/S0928-4869(00)00026-4

MISAU. (2010). Plano de Acção Multissectorial de Redução da Desnutrição Crónica em Moçambique EM MOÇAMBIQUE 2011 - 2014 (2020). Maputo: Ministério da Saúde. Retrieved from http://apps.who.int/nutrition/landscape_analysis/MozambiqueNationalstrategyreductionstunting_Portuguese .pdf

Mmasa, J. J., \& Msuya, E. E. (2012). Mapping of the Sweet Potato Value Chain Linkages between Actors, Processes and Activities in the Value Chain: A Case of "Michembe" and "Matobolwa" Products. 
Sustainable Agriculture Research, 1(1), 130-146. http://dx.doi.org/10.5539/sar.v1n1p130

Mmasa, J., Msuya, E., \& Mlambiti, M. (2013). Performance of various marketing channels for sweet potato value added products. Journal of Agricultural Economics and Development, 2(2), 65-76. Retrieved from http://academeresearchjournals.org/download.php?id=494503924275259385.pdf\&type=application/pdf\&op $=1=$

Mubai, B. A. (2014). Os serviços de Extensão Agrária Públlica ao Pequeno Agricultor familiar do distrito de Boane (Tese de Mestrado, Universidade Estadual de Maringá, Maringá, PR, Brasil). Retrieved from http://www.pge.uem.br/documentos-para-publicacao/dissertacoes-1/dissertacoes-2014-pdfs/BoaventuraMub ai.pdf

Raikes, P., Jensen, M. F., \& Ponte, S. (2011). Global Commodity Chain Analysis and the French Filière Approach: Comparison and Critique. Economy and Society, 29(3), 380-417. https://doi.org/10.1080/03085140050084589

Rodrigue, J.-P., Comtois, C. \& Slack, B. (2006). The geography of transport systems (3rd ed.). Routledge, New York, NY. Ruel, M. (2001). Can food-based strategies help reduce vitamin A and iron deficiencies? A review of recent evidence. Food Policy Review 5. Washington, D.C.: International Food Policy Research Institute (IFPRI). Retrieved from http://ebrary.ifpri.org/cdm/ref/collection/p15738coll2/id/79381]

Ruel, M., Alderman, H., \& The Maternal and Child Nutrition Study Group. (2013). Nutrition-sensitive interventions and programmes: how can they help to accelerate progress in improving maternal and child nutrition? The Lancet, 382 (9891), 536-551. http://dx.doi.org/10.1016/S0140-6736(13)60843-0

Smart, T., \& Hanlon, J. (2014). Chickens and beer: A recipe for agricultural growth in Mozambique. Bicycle+Development Ltd. Retrieved from https://www.open.ac.uk/technology/mozambique/sites/www.open.ac.uk.technology.mozambique/files/files/ Chickens_and_beer-a_recipe_for_growth_in_Mozambique.pdf

Sundkvist, A., Milestad, R., \& Jansson, A. (2005). On the importance of tightening feedback loops for sustainable development of food systems. Food Policy, 30, 224-239. https://doi.org/10.1016/j.foodpol.2005.02.003

Tedesco, I., \& Stathers, T. (2015). Sweetpotato value chains in Kenya: a business opportunity for puree processing and the potential role for commercial fresh root storage. NRI Report, Chatham: University of Greenwhich. Retrieved from http://www.sweetpotatoknowledge.org/wp-content/uploads/2016/01/MK_OBJ4MS1.1.A_REP0002_F_20 15_STATHERS_SWEETPOTATO-VALUE-CHAIN-WESTERN-KENYA.pdf

Time Magazine. (2018, June 07). The 25 Best Inventions of 2016. Retrieved from http://time.com/4572079/best-inventions-2016/

Tumwegamira, S., Mtunda, R., Andrade, M., Low, J., Semakula, G., Laurie, S., ... Grüneberg, W. (2013). Catalogue of orange-fleshed weetpotato varieties for Sub-Saharan Africa. Lima, Peru: International Potato Center (CIP). https://dx.doi.org/10.4160/9789290604396

Underwood, B., \& Arthur, P. (1996). The contribution of vitamin A to public health. The FASEB Journal, 10(9), 1040-1048.

West, K., \& Darnton-Hill, I. (2008). Vitamin A Deficiency. In R. D. Semba, M.W. Bloem \& P. Piot (Eds.), Nutrition and health in developing countries (pp. 377-433). Totowa, NJ: Humana Press. https://dx.doi.org/10.1007/978-1-59745-464-3

WHO. (2016, July 25). Biofortification of staple crops. Retrieved from e-Library of Evidence for Nutrition Actions (eLENA). Retrieved from http://www.who.int/elena/titles/biofortification/en/

Williamson, O. (1971). The vertical integration of production: Market failure considerations. American Economic Review, 61(2), 112-123.

\section{Copyrights}

Copyright for this article is retained by the author(s), with first publication rights granted to the journal.

This is an open-access article distributed under the terms and conditions of the Creative Commons Attribution license (http://creativecommons.org/licenses/by/3.0/). 